\title{
Oyster Cultivation and Related Researches in the British Isles.
}

\section{By Dr. J. H. ORton.}

AERY small proportion of the oysters sold in A the British Isles is taken directly from public grounds inshere or offshore. Natural offshore oyster beds become fished out soon after they are found, as a result of indiscriminate fishing, and inshore public beds suffer the same fate unless fishing is suitably restricted. The difficulties in enforcing culture on public grounds have led to the leasing of the chief oyster beds in Britain to private individuals or companies or corporate bodies. Thus the bulk of the oyster supply is produced by vyster cultivation of some kind.

The English native oyster (Ostrea edulis) is in its essential characters the same as the Dutch and the flat French oyster, therefore young Dutch and young flat French oysters may be laid down on English beds to grow and wax fat, and then be only recognisable as of foreign origin by an expert. Large numbers of the Portuguese oyster (Ostrea angulata) are now produced in France, and an increasing number is being imported into England and sold after remaining on English beds for one or more years. American oysters (Ostrea virginica) are also imported from Canada and America, and similarly relaid and sold after remaining on English beds for one or more years. Neither of these two latter species breeds naturally in any quantity in England. Thus oyster production in England is concentrated chiefly on Ostrea edulis.

In the British Isles, oyster cultivators fall into two chief groups, namely, one concerned in producing young oysters in great quantity and rearing them to an age of 2 to 4 years for sale to the other group, whose business it is to buy medium-sized oysters, grow them, and place them on the market in a plump or fat condition: the former are oyster producers; the latter, oyster merchants. On some producing grounds suitable portions of the beds may be utilised for rearing oysters for direct sale to the public, while on well-stocked fattening grounds good crops of young oysters may sometimes be obtained. Other beds, which have been condemned as being liable to pollution by sewage, may still be used for oyster culture, but all oysters produced on them must be transplanted for purification ${ }^{14}, 17$ before being offered for sale for consumption.

\section{Natural Oyster Cultivation.}

The cultivation of oysters (hereafter assumed to be $O$. edulis) may be considered in three natural stages: (1) oyster production, (2) growth culture, (3) fattening, but during all these stages the care of the beds forms an important fourth section of the work.

\section{Oyster Production.}

Individual female-functioning English oysters (O. edulis) produce from a few hundred thousand to about $1 \frac{1}{2}$ million eggs in a breeding season, according to the size of the individual. The eggs are laid inside the shell and are retained there by the parent until they develop into freely swimming individuals (larvoe) which, after a short hazardous life, 10 days or more, ${ }^{1}$ in the tidal streams, settle down on any suitable clean object and transform themselves into the sedentary young oyster, which at this stage is called an oyster spat. The season's settlement of young oysters is thus called a spatfall.

The primary object of the oyster producer is to secure a large spatfall. To attain this object the oyster cultivator must know the main facts regarding breeding and the best conditions for the settlement of the larvæ, and must keep a reasonably large stock ${ }^{2}$ of large spawning oysters to ensure a spatfall in only moderately good seasons. The beginning of the breeding season in $O$. edulis varies locally and with season according to the weather conditions from about the middle of May to the beginning of July. On English beds it has

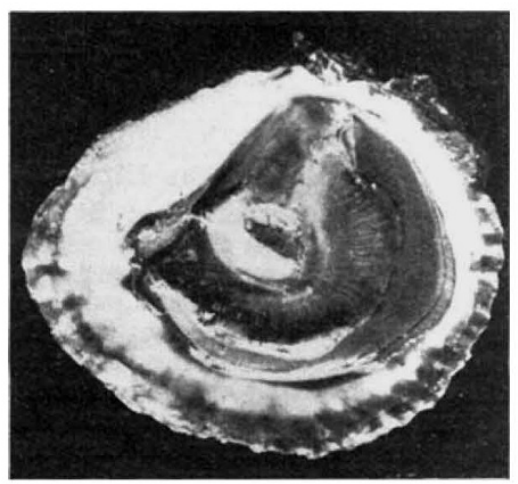

Fro. 1.-Photograph of a 'blacksick' oyster. The semi-lunar shaped black area in the upper right part of the shell is composed of hundreds of thousands of shelled larvæ. Individual larvæ may be distinguishable with a lens in the original on the lower middle part of the shell. $\left(\times c a . \frac{3}{4}.\right)$

been found that breeding begins in a fair proportion, 10 to 20 per cent ${ }^{3}$ of the population, soon after a temperature of $60^{\circ} \mathrm{F}$. or above is maintained in the bulk of the seawater. In practice the oyster cultivator examines ${ }^{4}$ samples of oysters at about the usual time breeding begins in a particular locality until a small proportion of blacksick ${ }^{5}$ oysters are found. A blacksick oyster is one containing larvæ which appear black in mass, in which condition they are ready to begin a free existence (Fig. 1).

As soon as a small percentage ${ }^{6}$ of blacksick oysters are found, a previously prepared quantity of clean shell is gradually spread day by day over those portions of the beds known to have secured spatfalls in other seasons. Any kind of clean material, but especially shell, whether of cockles, oysters, mussels, limpets, or clean shell-gravel, and collectively called cultch, may be used. Twenty tons of this material is easily absorbed on even small beds. The English method of catching spat by merely throwing clean shell into the sea is very

No. 3093 , VoL. 123] 
simple and primitive in comparison with continental and other foreign methods, ${ }^{7}$ but is defensible on the high cost of labour in this country and the (im)probability of adequate economic return on outlay on extra labour costs.

After the distribution of the cultch, the oyster cultivator, like the farmer on land, is-except for nursing the beds-largely at the mercy of the weather. After a long fine summer a good fall of spat may be expected on most well-stocked beds; but the spatfall may fail in some good summers, or in other rare cases be so prolific as to bespatter almost every available object, including some fucoid seaweeds. In cold summers a good spatfall is not expected. These facts prove that certain special conditions, which do not always occur in the sea, are requisite for the proper development of the larvæ and/or the transformation which occurs when the active larva settles down to become the sedentary mollusc. In a good season, upwards to 30 spat on an oyster shell may be found about the middle of July; in a poor one, shells with 2-5 spat may be difficult to find, and, except in prolific seasons, there is probably a heavy mortality at this stage.

\section{Growth Culture.}

When the cultivator has obtained a good spatfall, the young oysters are left on the ground undisturbed until at least the following winter or spring, and usually until the size of one inch or more is attained. At about the size of $1 \frac{1}{2}$ to 2 inches, the young oysters in the sea begin mostly to grow away from the cultch shell, and can then be, and are, freed therefrom with a knife, one of the operations known as culling. Culling the young oysters from cultch is an important operation and permits the animal afterwards to grow into a good shape, that is, with a deeply concave as opposed to a flat shell. After being culled, the young oysters may be returned to the original bed, or relaid on special nursery beds kept for particular size-groups, and left to grow under supervision until required for sale or relaying on fattening beds. Well-shaped oysters grown in the sea rarely attain to more than a length of one inch at an age of one year, ${ }^{2}$ and afterwards on the average increase in size (length) with a decreasing yearly increment; on the other hand, flat-growing oysters may grow in length at a greater rate than one inch per year. In the sea, increase in shell area occurs in the spring and again in late summer or autumn, as is especially well shown on the Fal Estuary Beds. In the apparent dormant period in summer there is some reason to believe ${ }^{8}$ that the shell may be increasing in thickness. Well-shaped oysters usually grow slowly in size, and rarely attain marketable size before having spent five summers in the sea.

\section{Fattening.}

The natural fattening of oysters consists simply in relaying stock on whole beds or parts of beds where previous experience has shown that fattening will usually occur. The oysters fatten themselves naturally, but in the sea there are also good and bad years for fattening, although certain beds rarely fail. Fattening depends ultimately upon the occurrence of an abundant supply of microscopic vegetable food, especially diatoms and peridinians. ${ }^{9}, 10$. In the sea the amount of this food available shows fluctuations, 9, 11 with usually maximal growths in spring and late summer or autumn, and the natural fattening of oysters at the approach of winter is believed to be dependent upon the later maximum. ${ }^{9}$ In France, oysters are artificially fattened in ponds or claires by feeding them with a superabundance of diatoms. If, therefore, by artificial means a superabundance of microscopic vegetable organisms could be produced cheaply in restricted estuarine localities in the sea, the fattening of the contained oysters, if these were otherwise healthy, would be assured.

In spring and summer the food absorbed is utilised largely in the formation of reproductive products. When an oyster is ready to spawn it is usually in fine fat condition, but in this condition the fatness is due to the great development of eggs or sperm, whereas the fatness attained on the approach of winter is quite different ${ }^{\mathbf{9}}$ and due to an accumulation of food reserves. ${ }^{12}$

\section{Care of the Beds.}

During all the preceding phases of oyster culture a constant watch on the beds is maintained for the purpose of collecting and destroying pests and enemies, such as, on one hand, slipper-limpets, mussels, ascidians, and on some grounds the larger seaweeds, and on the other hand, the oyster-borers, Murex, Purpura, and Urosalpinx, and starfishes. Muddy beds may need to be harrowed, and sandy beds inspected after a succession of gales, or after gales of unusual severity, while constant supervision may be required to prevent or detect poaching.

\section{Artificial Oyster Production.}

The well-known fact that one individual $O$. edulis at an age of about six years may incubate one million or more young to an advanced stage of development has presented an alluring prospect of easily acquired wealth to experimental cultivators for more than half a century. Many attempts have been made in the past in specially constructed oyster ponds and tanks to obtain young oysters from the millions of larvæ which can easily be obtained in such ponds or tanks, but with economic failure. Large spatfalls have been obtained in some years, followed by complete failure in many others. Such experiments in the past, however, have been based on empirical procedure, and there is no reason to suppose that success will not ultimately be attained as the factors concerned in promoting (1) the healthy life of the larvæ, (2) an easy transformation of the larva to spat, and (3) an assured early development of the spat become known. The experience gained in rearing the larvæ of seaurchins, crabs, ascidians, limpets, worms, and even crabs at the Plymouth laboratory, ${ }^{13}$ all tends to show that the undertaking is more difficult than would be anticipated. The difficulty is also 
generally greater when there is-as in the case of the oyster-a metamorphic stage in the development, at which stage there is generally a very great mortality. Academic researches on rearing marine animals have, however, been made only on a small scale, and additional difficulties arise when it is necessary to carry out experiments in a large volume of unchanged-but changing-water.

In recent years the Government Fisheries Department has attacked the problem of the artificial production of oysters in the mussel purification tanks at Conway, with variable, but probably greater, success than has attended previous efforts. The Government experiments were begun on empirical lines in the post-War period, but are now being continued on a scientific plan, ${ }^{14}$ which is taking into account all the factors likely to affect a successful issue, such as nature of the larval food, constituents of the water, enemies, as well as temperature conditions; ultimate success in obtaining falls of millions of spat is probably only a question of time. The recent recognition of the importance of the minor chemical constituents ${ }^{15}$ of sea-water, especially in a stationary body of water, has widened the scope of these experiments, but at the same time narrows down the possible.unknown factors. The problem is thus expanding beyond the province of the biologist, and whether the original staff is big enough-even with hearty outside co-operation-to press the investigation with vigour may be reasonably doubted.

The original idea of these experiments was to discover whether oysters could be produced in bulk in tanks on a commercial scale. Oysters have been produced in large quantities, but the commercial aspect has not yet been sufficiently considered. Millions of oysters may be procured in tanks, but unless a reasonable proportion are eventually put on the market at a profit, the project is commercially unsound. It is desirable, therefore, that a largescale commercial experiment should be carried out side by side with investigations into the exact conditions for ensuring a large spatfall.

\section{Artifictal Fattening.}

The success of continental cultivators in fattening oysters artificially leaves no doubt that the same process-if commercially desirable-could be carried out in England by supplying a superabundance of diatoms in tanks or ponds. Such oysters are, however, usually green-gilled, and are not favoured by the English consumer, so that the problem in artificial fattening in England would comprise also the production of a white 'fish.'
Recent researches, ${ }^{10}$ however, indicate that a superabundance of diatoms and/or peridianians might be obtained in closed estuarine waters by artificially maintaining the slight concentration of essential foodstuffs, phosphates and nitrates, necessary for heavy crops of this planktonic vegetation. Supplied with abundant food of this nature, oysters would fatten naturally and with a minimum of outlay on labour.

\section{Research Problems.}

The main research problems in connexion with oyster culture are those concerned with increasing the stock of young individuals and with fattening oysters for the market. While the artificial production of young oysters may eventually be an assured commercial proposition, it is possible that slight improvements in the methods of securing oyster-spat on the natural oyster beds may rival even successful artificial methods in the ultimate return on outlay. Experiments on the treatment of shell-cultch before distribution in the sea, and novel methods of catching spat in the sea are reasonable problems for research.

The liaison between the oyster cultivator and the Fisheries Department is rendered difficult by the private or semi-private nature of most oysterfisheries, but mutual benefit would undoubtedly follow if a young Government oyster-biologist were assigned the special duty of studying and conducting continuous researches on oyster culture and its problems in all parts of Great Britain. The biologist would be able to help the practical man in everything relating to biology, such as sex, spawning, development, spatfall, feeding, exposure dangers, etc., and in return would learn a great deal about the bionomics of the oyster in its relation to culture, ${ }^{16}$ the local problems in oyster culture, and would eventually become a beneficent expert.

\section{REFERENCES}

1. Spawning. Orton, Jour. M.B.A., 14, $222 ; 1926$

2. Culture. Orton, Report on a Survey of the Fal Estuary Oyster Beds, etc., Falmouth, 63, 22; 1926 .

3. Spawning Epoch. Orton, Jour. M.B.A., 14, Fig. 3, $210 ; 1926$

3. Spawning Epoch. Orton, Jour. M.B.A., 14, Fig. 3, 210; 1926.

4. Blacksick Testing. Orton, Fish Trades Gazette, June 30,

5. Laying Cultch. Orton, Ibid., 14.3, 621; 1927.

6. Laying Cultch. Orton, Ibid., 14, 3, 621 ; 1927. 1927 , in the press.

8. Shell-growth. Havinga, Jour. du Conseil. Int., Copenhagen, 3 , 2,$231 ; 1928$.

9. Food and Fattening. Savage, Fish. Invest., London, 8, 1 ; 1925.

10. Food and Fattening. Savage, Fish. Invest., London, 8, $1 ; 1925$.

11. Plankton Maxima. Lebour, Ibid. 11, 2, 141; 1917.

12. Food Reserves. Russell, Fish. Invest., London, 6, 1, 7; 1923

13. Rearing Larvæ. Allen and Nelson, Jour. M.B.A., 8, 421 ; 1907. 14. Artificial Purification and Production. Dodgson, Fish. Invest. London, 10, 1, 346; 1928.

15. Food Limiting Factors, Atkins, Jour, du Conseil. Int., Copenhagen, 1,$3 ; 1926$.

16. Bionomics and General. Orton, Fish. Invest., London, 6, 3 and 4 ; $1923-4$.

17. Purity. Orton, Jour. Roy. San. Inst., 49, 263; 1928.

\section{Vitamin D and the Structure of Human Teeth.}

$\mathrm{I}^{\mathrm{N}}$ $\mathrm{N}$ a recent review in Nature (Vol. 121, p. 325 ; 1928) on the influence of diet upon the teeth, reference was made to the work of M. Mellanby and her collaborators on the effect of diet on the structure of the teeth and on the incidence of caries. More recently the same author has brought forward evidence indicating a definite relationship between structure and the incidence of caries, and has also shown that it is possible to arrest the spread of this condition by suitable alterations in the diet (M. Mellanby, Brit. Dental Jour., Dec. 15, 1927 ; M. Mellanby and C. L. Pattison, Brit. Med. Jour., vol. ii, p. 1079 ; 1928).

An analysis of the results obtained from the

No. 3093, VoL. 123] 